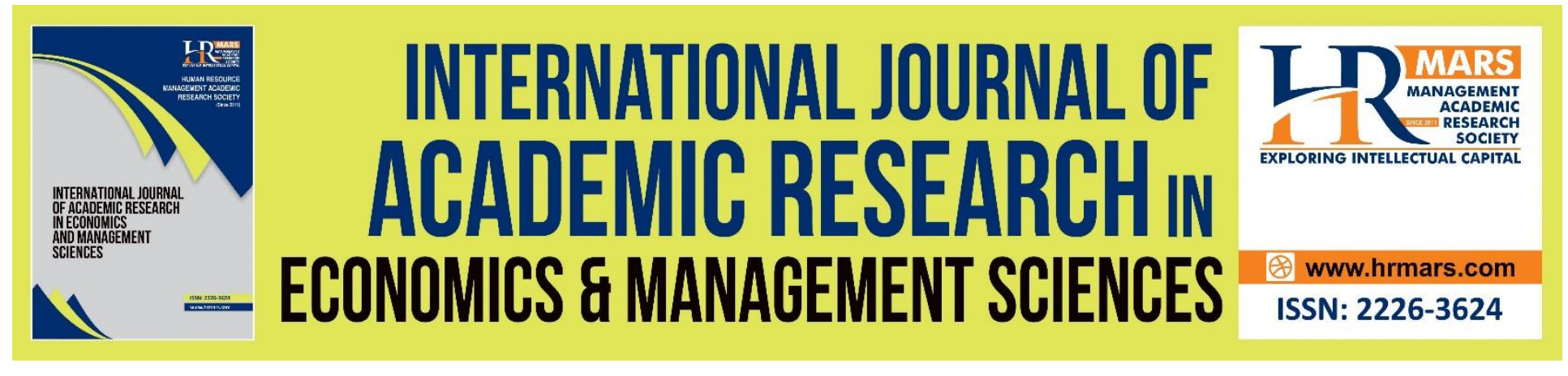

\title{
Establishing Recycling Bins Location and Allocation for Sustainable Urban Municipalities of Johor Bahru in Malaysia
}

\author{
Nur Fatnun Hidayah Jamiron, Nur Atiqah Sarhawi Sarif, Nur Sabrina Abdul \\ Rahman, Zati Aqmar Zaharudin
}

To Link this Article: http://dx.doi.org/10.6007/IJAREMS/v10-i3/11344

DOI:10.6007/IJAREMS/v10-i3/11344

Received: 30 July 2021, Revised: 28 August 2021, Accepted: 14 September 2021

Published Online: 26 September 2021

In-Text Citation: (Jamiron et al., 2021)

To Cite this Article: Jamiron, N. F. H., Sarif, N. A. S., Rahman, N. S. A., \& Zaharudin, Z. A. (2021). Establishing Recycling Bins Location and Allocation for Sustainable Urban Municipalities of Johor Bahru in Malaysia. International Journal of Academic Research in Economics and Management and Sciences, 10(3), 459-472.

Copyright: (C) 2021 The Author(s)

Published by Human Resource Management Academic Research Society (www.hrmars.com)

This article is published under the Creative Commons Attribution (CC BY 4.0) license. Anyone may reproduce, distribute, translate and create derivative works of this article (for both commercial and non-commercial purposes), subject to full attribution to the original publication and authors. The full terms of this license may be seen at: $\underline{\text { http://creativecommons.org/licences/by/4.0/legalcode }}$

Vol. 10, No. 3, 2021, Pg. 459 - 472

http://hrmars.com/index.php/pages/detail/IJAREMS

JOURNAL HOMEPAGE

Full Terms \& Conditions of access and use can be found at

http://hrmars.com/index.php/pages/detail/publication-ethics 


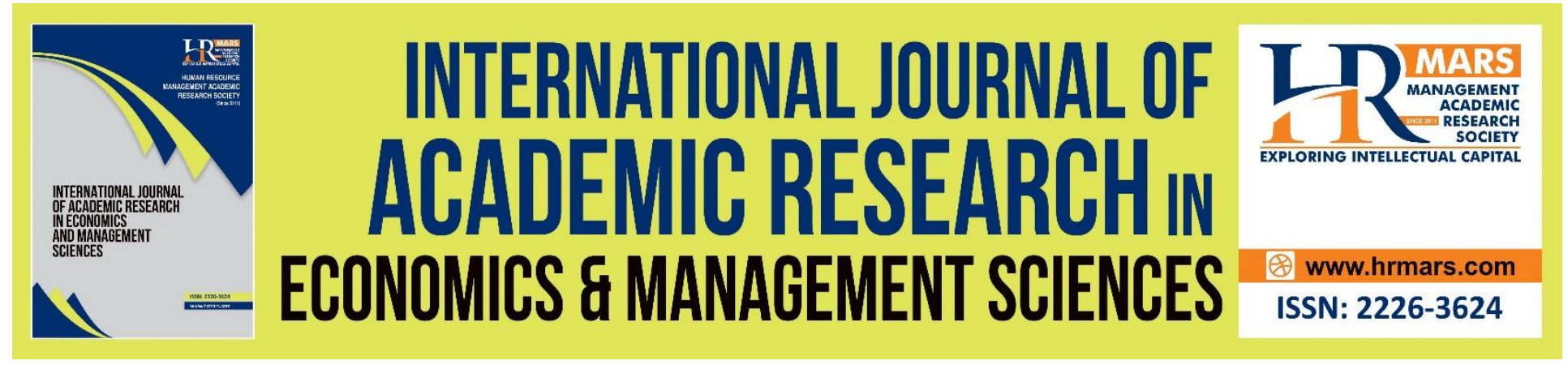

\title{
Establishing Recycling Bins Location and Allocation for Sustainable Urban Municipalities of Johor Bahru in Malaysia
}

\author{
Nur Fatnun Hidayah Jamiron, Nur Atiqah Sarhawi Sarif, Nur \\ Sabrina Abdul Rahman, Zati Aqmar Zaharudin
}

Faculty of Computer and Mathematical Sciences, Universiti Teknologi MARA Cawangan Negeri Sembilan, Kampus Seremban, Negeri Sembilan, Malaysia

Email: zati@uitm.edu.my

\begin{abstract}
Recycling helps reduce the amount of waste sent to landfills besides being one of the most crucial components of the circular economy system. This good practice is carried out through reverse and forward logistic systems and is in line with two Sustainable Development Goals (SDGs), namely SDG 11 (make cities inclusive, safe, resilient, and sustainable) and SDG 12 (responsible consumption and production). Since the 1970s, Malaysia's government has been committed to strengthening recycling systems, but public support has been lacking. In fact, most recyclable waste is sent to the landfill. A high degree of participation in recycling practices by the highest municipal waste generators, i.e., the household level, is critical. Encouraging waste separation at the household level, as well as providing appropriate locations for recycling facilities (such as drop-off recycling bins), could attract public participation in recycling programmes, resulting in higher recycling rates, and lowering waste sent to landfills. For this reason, this study determines the location and allocation of recycling bins within the selected household areas of Johor Bahru, an urban municipality in Malaysia, by using a mathematical model. The model was found to be capable of determining the optimal location-allocation for recycling bins to cover the study area. Keywords: Facility Location, Waste Management, Recycling, Circular Economy, Sustainable Development Goals
\end{abstract}

\section{Introduction}

The growing population causes an increase in waste generation, particularly in urban areas. Municipal solid waste (MSW) is always a challenge for local authorities when it comes to developing smart and sustainable municipalities. MSW management (MSWM) includes collecting, transporting, processing, recycling or disposal, and monitoring waste materials (Demirbas, 2011). MSW must be managed sustainably as it is an essential element of guaranteeing better environmental quality, particularly in the context of lowering pollution and 
carbon emission levels. Currently, landfills are the most preferred waste disposal option in most Southeast Asia countries, including Malaysia (Ngoc \& Schnitzer, 2009).

As a developing country with a growing population, Malaysia is also experiencing waste management issues. MSWM in Malaysia has experienced a transition since 1960 until official solid waste management legislation was fully implemented in 2011 (Abas \& Wee, 2016). For 2018, the amount of solid waste generated in Malaysia was estimated to be about 38,200 tons per day (1.12 kg/cap/day) (Imran et al., 2019). However, the country continues to rely on the landfilling approach to manage solid waste due to its low cost (Imran et al., 2019), although landfilling is the least preferred waste disposal method (Moh \& Abd Manaf, 2017). The present major hurdles in building a substantial MSWM system are poor implementation of waste legislation, lack of innovative infrastructures, and minimal public participation (Khamaruddin et al., 2019).

The Malaysian government has established a new waste management paradigm, as depicted in Figure 1, to address the increased volume of waste generation sustainably. As reported in the Green Technology Master Plan (GTMP) 2017-2030, through this paradigm, the collected waste is transferred to a station that serves as an intermediate step to make the waste collection system more efficient and cost-effective. Furthermore, current landfills will be equipped with innovative systems, new regional sanitary landfills and decommissioning lowperforming ones will be developed, and unsafe landfills will be upgraded. This strategy, unfortunately, is unsustainable in the long run since landfilling increases greenhouse gas emissions and directly contributes to global warming.

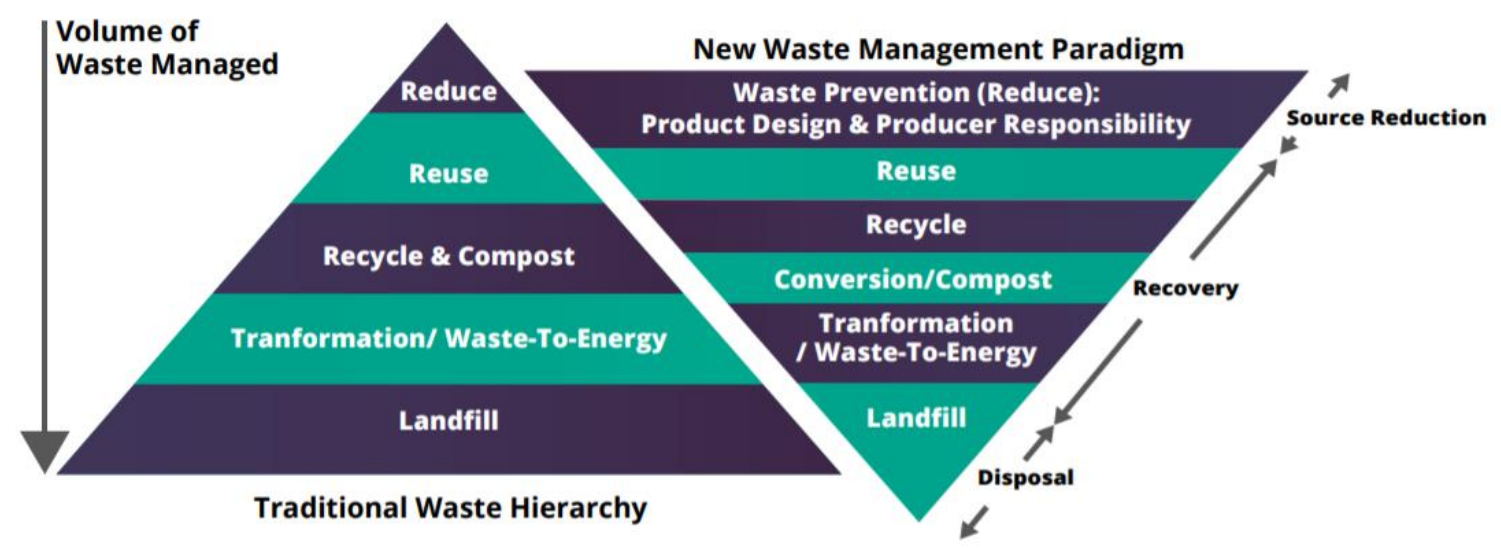

Figure 1: Diagram on Modern Methodology on Waste and Landfill Management (source: KeTTHA, 2017)

It was reported that Malaysia's recycling rate is $28.1 \%$ for the year 2020, exceeding the targeted rate of 22\% ("Compendium of Environment Statistics, Malaysia 2020," 2020). However, approximately $80 \%$ of municipal solid waste disposed of at landfills is recyclable (Michel Devadoss et al., 2021; Moh \& Abd Manaf, 2014). In fact, only 20\% of the collected solid waste could be sent to the landfill (Shahrul Annuar, 2019). Through the Comprehensive Action Plan of Solid Waste Management 2015-2020, the Malaysian government proposed strategies on source separation 
and recycling by improving recycling facilities and providing more recycling bins in public locations (Moh \& Abd Manaf, 2017).

Household waste is currently disposed of in a bin or container on the premises and collected by regional private concessionaires in Malaysia (Tan et al., 2015). Despite being the largest generators of solid waste (Razali et al., 2019), unfortunately, waste reduction initiatives like the 3Rs (reduce, reuse, recycle) are slowly progressing (KeTTHA, 2017). Furthermore, waste separation at the point of generation is critical for implementing reuse and recycling practices (Umar et al., 2021). Therefore, it is essential to encourage the use of on-site recycling facilities, particularly recycling bins in their locality. More waste can be recycled and later reused if recycling bins are easily accessible and available. Proper reuse and recycling of waste materials can save energy, reduce $\mathrm{CO}_{2}$ emissions (Umar et al., 2021), directly reduce the amount of waste sent to landfills, and induce the government financially (Razali et al., 2020). Besides being the key to fostering the circular economic transition (Zaharudin et al., 2021), recycling reflects the zerowaste principles while complying with two important Sustainable Development Goals (SDGs), i.e., SDG 11 (make cities inclusive, safe, resilient, and sustainable) and SDG 12 (responsible consumption and production).

Perhaps, location of a facility is difficult to change on immediate terms (Daskin et al., 2005), especially for waste management facilities, causing this area to gain less attention from the academic world. But, installing the on-site recycling facilities within the household area would positively contribute to sustainable municipal waste management. Our work substantially improves MSWM in Malaysia's urban municipalities by locating and allocating recycling facilities, especially on-site recycling bins, to encourage households' involvement in recycling practices. To do so, we utilized a mathematical model for facility location problems known as the Maximum expected coverage location problem (MEXCLP). The model's definitions of variables and parameters were adjusted, where a capacity constraint was introduced to solve for MSWM in the urban areas.

The remainder of the paper is divided into the following sections: section 2 examines past studies and focuses on the methods used. Section 3 describes the model for recycling facilities, and section 4 highlights the implementation procedures and presents the findings. Finally, section 5 concludes the study and addresses the future directions of our study.

\section{Related Past Studies}

Gilardino et al (2017) proposed mixed-integer linear programming (MILP) method for determining the number and location of waste and recyclable waste bins, as well as collection routes, in Lima, Peru, by minimizing the total number of regular and recyclable collection sites. Moreover, Blazquez and Paredes-Belmar (2020) also employed MILP methods in two stages to find waste collection containers in Renca, Santiago, Chile. The first stage is concerned with locating collection points and allocating the appropriate quantity of containers. The second stage involves determining the best route for waste collection service.

A combination of MILP and graphical information system (GIS) is utilized by Rathore, Sarmah and Singh (2020) to locate and allocate a number of several types of waste facilities, including recycling bins, in Bilaspur, India. The authors use GIS to extract the related data for the allocation of bins. Similarly, Letelier et al (2021) employ MILP and GIS approach to solve the bin location-allocation problem for household and recyclable waste. Classical facility location 
problems, namely, location set covering problem (LSCP) and the maximal covering location problem (MCLP), are used in the studies.

GIS is used to gather necessary details about the case study area. Several studies were found implementing GIS in their studies, such as Boskovic and Jovicic (2015), Nowakowski and Mrówczyńska (2018); Blazquez and Paredes-Belmar (2020); and Rathore, Sarmah and Singh (2020). For example, Boskovic and Jovicic (2015) and Nowakowski and Mrówczyńska (2018) used GIS as part of the procedure to locate the optimal waste collection points. Both studies considered vehicle collection routes and find the optimal number of containers at each point. Boskovic and Jovicic (2015) used ArcGIS Network Analyst to solve for Kragujevac, Serbia. Meanwhile, Nowakowski and Mrówczyńska (2018) focused on waste from electrical and electronic equipment (WEEE) and used an artificial immune system (AIS) to plan the waste collection system in Sfax, Tunisia.

Furthermore, Mirdar Harijani, Mansour, and Karimi (2017) developed a multi-objective (MO) MILP based on economic, environmental, and social criteria to identify an MSW network focused on recycling and disposal in Tehran, Iran. The authors employed a similar approach with a multi-period element to depict the dynamic in the amount of generated waste, transportation, and operational costs. Meanwhile, Asefi and Lim (2017) employed the same considerations to solve the locations, capacities, and routes of several types of MSWM facilities, including recycling facilities in Tehran, Iran, by integrating a multi-criteria decision making (MCDM) method within a GIS context.

In addition, Rosni et al. (2021) use conventional facility location problems to locate and allocate recycling facilities in Malaysian urban municipalities. The authors enhanced the MEXCLP by imposing an availability constraint to ensure that the allocated recycling bins provide sufficient capacity for all demand areas. So, for our study, we enhanced the MEXCLP model by limiting the total number of permissible recycling bins in each specified area following the authors' work. It is also observed that studies related to recycling facility locations in Malaysia using mathematical approaches are still lacking. However, a comprehensive overview of Malaysian recycling practises can be found, such as studies by Abdul Malik et al (2015); Razali et al (2020) that focus on Malaysians' recycling practice and community participation in urban areas. Meanwhile, Sharifah et al (2018); Yusoff (2018); Khamaruddin et al (2019); Tiew et al (2019) focused on the recycling behaviour and practices of Malaysian's higher institutional area. Therefore, implementing a mathematical model to the Malaysian context of locating and allocating recycling facilities will be advantageous to the enrichment of literature.

\section{Methodology}

This study's methodology focuses on enhancing MSWM in Malaysia's urban municipalities by locating and allocating recycling facilities, particularly on-site recycling bins, to increase household engagement in recycling practices.

\section{Mathematical Model}

In this study, we enhanced the work of Rosni et al (2021), where the mathematical model is as follows. 


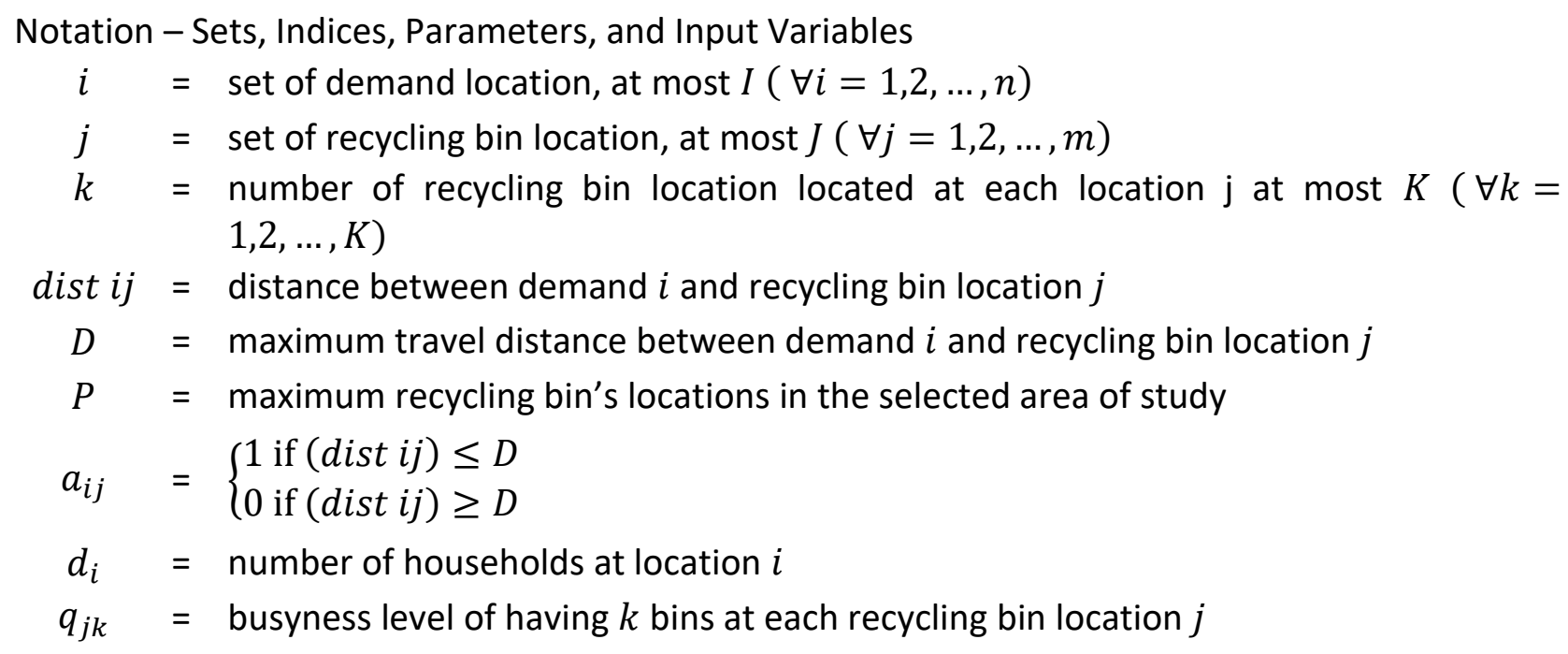

Decision Variables

$$
\begin{aligned}
& x_{j}= \begin{cases}1 & \text { if a recycling bin is located at } j \\
0 & \text { otherwise }\end{cases} \\
& y_{i k}=\left\{\begin{array}{lr}
1 & \text { if demand at location } i \text { is covered with } k \text { bins } \\
0 & \text { otherwise }
\end{array}\right.
\end{aligned}
$$

Model Formulation

$$
\operatorname{Maximize} \sum_{i}^{n} \sum_{j}^{m} \sum_{k}^{K} d_{i} q_{j k} y_{i k}
$$

subject to:

$$
\begin{array}{ll}
\sum_{k}^{K} y_{i k}-\sum_{j}^{m} a_{i j} x_{j} \leq 0 & , \forall i=1,2, \ldots, n \\
\sum_{j=1}^{m} x_{j} \leq P & \\
\sum_{k}^{K} y_{i k} \leq 1 & , \forall i=1,2, \ldots, n
\end{array}
$$

Equation (1) indicates the objective function to maximize the amount of demand I covered by selected $j$ facilities with the allocated $k$ facilities. Constraint (2) ensures selected facility location $j$ can cover all demand $i$. Constraint (3) limits the maximum number of recycling facilities in an area of study $j$ at $P$ locations. Constraint (4) establishes limits to the designated $k$ bins for each demand at location $i$. This constraint also specifies the total allocation of bins at the selected location $j$ while ensuring sufficient bin capacities. In the proposed model, the availability concept in the objective function (1) is adapted from Shuib and Zaharudin (2011) where 


$$
q_{j k}=1-\left(b_{j}\right)^{k} \quad, \forall j=1,2, \ldots, m
$$

For our study, the $\left(b_{j}\right)^{k}$ indicates the busyness level of facility $j$ with the number of $k$ bins. This value is gained from $b_{j}=\frac{\sum_{i=1}^{n} d_{i} a_{i j}}{\sum_{i=1}^{n} d_{i}}$ i.e., the capability of facility $j$ to cover demand for the area $i$. The number of recycling bins in an area depends on the constraints imposed by the provider. Therefore, for our study, two additional constraints are introduced, which are (i) a limitation on total bin allocation and (ii) to ensure each selected recycling bin locations are able to cover its locality area. The formulations are as follows:

$$
\begin{aligned}
& \sum_{k}^{K} \sum_{i}^{n} k \cdot y_{i k} \leq M \\
& \quad \sum_{k}^{K} y_{i k} \geq a_{i j} x_{j} \quad, \forall j=1,2, \ldots, m ; \forall i=1,2, \ldots, n .
\end{aligned}
$$

Constraint (6) limits the total recycling bins located of the study area at most $M$. Meanwhile, (7) ensures each designated $j$ covers its demand area $i$. Both constraints are useful in ensuring the total recycling bins located at the area of interest are sufficient with the amount of demand, at the same time, giving an insight of possible solutions to the decision-makers.

\section{Case study - Johor Bahru}

The location of Johor Bahru within the Johor state is shown in Figure 2. The city is managed by three city councils, namely, Iskandar Puteri City Council (MBIP), Johor Bahru City Council (MBJB), and Pasir Gudang City Council (MBPG). As of 2019, 43\% or a population of 1.6 million of Johor state's population resides in Johor Bahru (Basic Data \& Johor State Economic Data, 2020). Figure 2 also highlights our area of study that is located within the MBIP administrative area. There are 525,351 , or $33 \%$ of the Johor Bahru population, resides within the MBIP administrative area. 


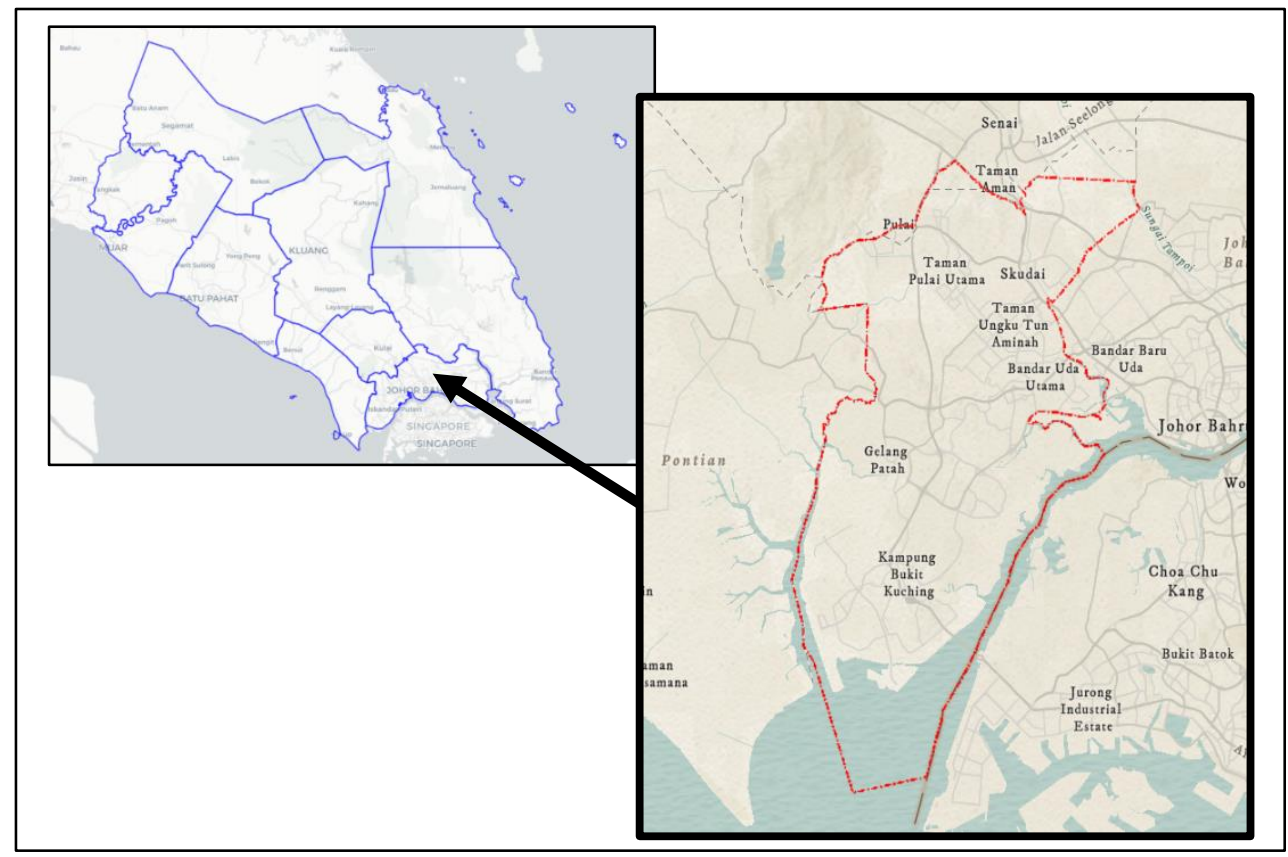

Figure 2: MBIJ jurisdiction area

Currently, the Solid Waste and Public Cleansing Management Corporation (SWCorp) and SWM Environment monitor and administer waste in Johor state. The corporation reported that Johor state generated a total of 3,600 tonnes of waste, including domestic waste per day (Suhaini, 2019). In particular, almost 1,200 tonnes ${ }^{1}$ of wastes are from MBIP administrative area. It was also stated that the majority of the state's landfills are nearing the end of their useful life (Hammim, 2019); hence a sustainable and optimal alternative for the landfilling method is urgently needed.

MBIJ is part of local councils that are involved with the Iskandar Malaysia Regional Development Authority, that targeted on Low Carbon Society for Iskandar Malaysia by 2030 in order to minimize carbon dioxide $\left(\mathrm{CO}_{2}\right)$ emissions and develop waste management infrastructures, specifically, innovative recycling plants, to reduce plastic wastes sent to landfills (Musa, 2021). Clearly, the need to have recycling facilities in Johor Bahru is critical. However, as far as our concern, no study focused on implementing a mathematical approach for locating recycling bins in Johor Bahru residential area.

So, as a pilot study, we concentrated on an urban area within the MBIJ jurisdictions, specifically the selected residential Mutiara Rini, to locate and allocate recycling bins using a mathematical approach. Figure 3 depicts the selected study area. Within this area of study, there are recreational areas, a shopping complex, supermarkets, and other facilities such as clinics and schools. Therefore, the necessity for optimal recycling bins in strategic locations is critical since these areas are highly accessible to residents and visitors.

${ }^{1}$ Amount of waste generated per day $=3,600$ tonnes $x 33 \%$ of population resides within MBIP administrative area $=1,188$ tonnes $/$ day. 


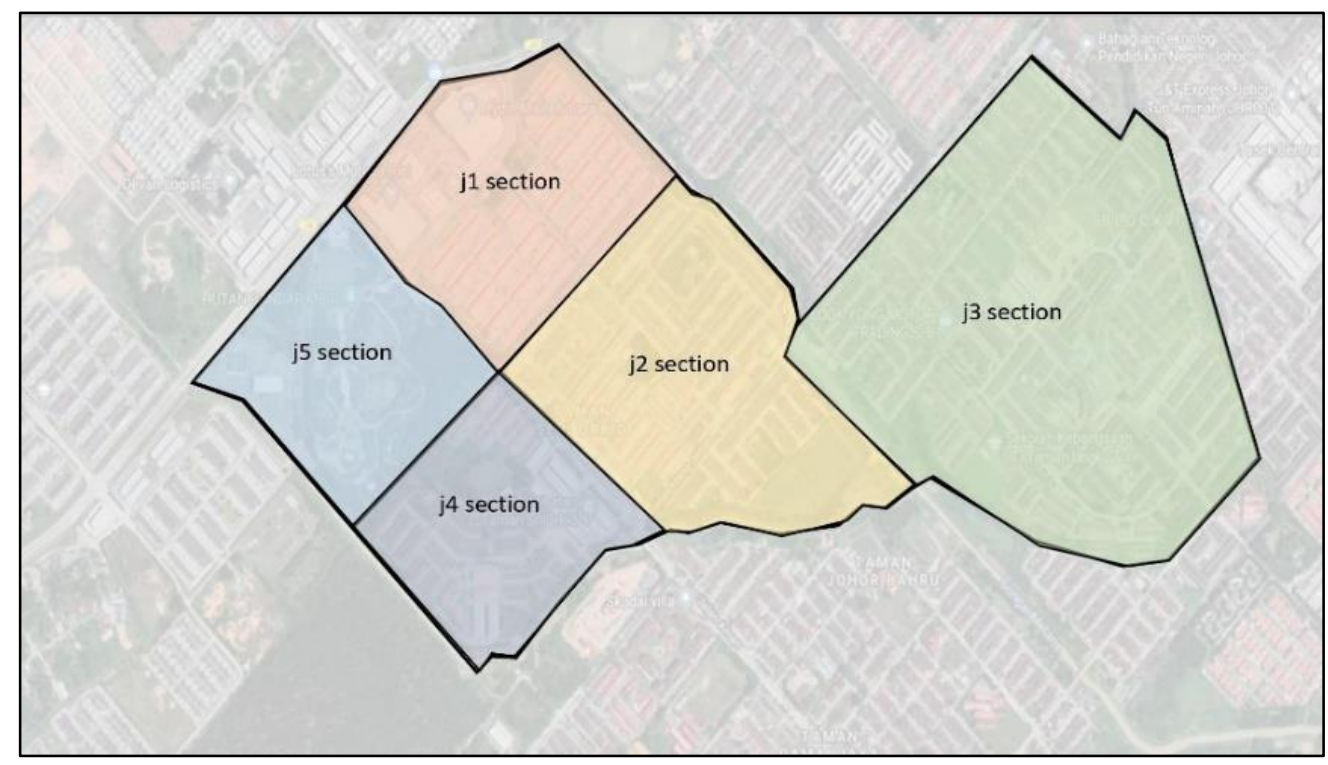

Figure 3: Case study area

\section{Data Descriptions and Assumptions}

Five household areas are selected, i.e., $I=5$. Given that potential recycling bin locations are within these areas, hence $J=5$. Meanwhile, the travel distance between these areas is gathered by using Google Maps, with an average of 5 minutes. Therefore, the maximum distance between the potential facility location and the demand area, $D$, is fixed at 5 minutes. This would also be beneficial because the study area is limited. As the study area is limited, the number of bin allocations, $k$, is varied at 1 or 2 bins. Note that the maximum total location of the recycling bin, $P$, and the total allowable recycling bins at the study area, $M$ has no limit since these values totally depend on the decision maker's preferences. Thus, to find the optimal solution for our case study, $P$ is designed to vary at $1,2, \ldots, M$ bins. For example, if $M$ is adjusted to $3, P$ varies at 1,2 or 3 locations. This means that three bins will be allocated at either one, two or three designated bins' locations. The model is solved using CPLEX 20.1 on a computer with a processor speed of $2.3 \mathrm{GHz}$.

Meanwhile, cost implications, particularly the cost of an innovative recycling facility, were not incorporated into the model. Therefore, we did not evaluate any financial implications from local authorities because we were primarily concerned only with a model application for the specific area. We also assume that the designated node of potential bin locations is accessible to the public at all times.

\section{Results and Discussion}

The findings of the study are presented in this section. First, the solution set is generated using the parameter adjustments provided in the preceding section. Then, the outputs were examined, and the most optimal location for recycling bins was established. Finally, we presented our findings using $k$ values, with $k=1$ (as shown in table 1) and $k=2$ (as shown in table 2). 
Table 1: Recycling bin locations and allocations within the selected residential areas of Mutiara Rini, Johor Bahru, with $k=1$

\begin{tabular}{llllll}
\hline$M$ & $P$ & $\begin{array}{l}\text { Recycling } \\
\text { locations }\end{array}$ & $\begin{array}{l}\text { bin's } \\
\text { coverage }\end{array}$ & $\begin{array}{l}\text { Percentage of } \\
\text { bins allocation }\end{array}$ \\
\hline 1 & 1 & - & - & - \\
\hline 2 & 1 & 3 & $40 \%$ & 2 \\
& 2 & 3 & $40 \%$ & 2 \\
\hline \multirow{3}{*}{3} & 1 & 3 & $40 \%$ & 2 \\
& 2 & 3 & $40 \%$ & 2 \\
& 3 & 3 & $40 \%$ & 2 \\
\hline \multirow{4}{*}{4} & 1 & 2 & $80 \%$ & 4 \\
& 2 & 2 & $80 \%$ & 4 \\
& 3 & 2,3 & $80 \%$ & 4 \\
& 4 & 2,3 & $80 \%$ & 4 \\
\hline \multirow{4}{*}{5} & 1 & 5 & $100 \%$ & 5 \\
& 2 & 4,5 & $100 \%$ & 5 \\
& 3 & $3,4,5$ & $100 \%$ & 5 \\
& 4 & $2,3,4,5$ & $100 \%$ & 5 \\
& 5 & $1,2,3,4,5$ & $100 \%$ & 5 \\
\hline
\end{tabular}

Table 2: Recycling bin locations and allocations within the selected residential areas of Mutiara Rini, Johor Bahru, with $k=2$

\begin{tabular}{|c|c|c|c|c|}
\hline$M$ & $P$ & $\begin{array}{l}\text { Recycling bin's } \\
\text { locations }\end{array}$ & $\begin{array}{l}\text { Percentage of } \\
\text { coverage }\end{array}$ & $\begin{array}{l}\text { Total recycling } \\
\text { bins allocation }\end{array}$ \\
\hline 1 & 1 & - & - & - \\
\hline \multirow{2}{*}{2} & 1 & 3 & $40 \%$ & 2 \\
\hline & 2 & 3 & $40 \%$ & 2 \\
\hline \multirow{3}{*}{3} & 1 & 3 & $40 \%$ & 3 \\
\hline & 2 & 3 & $40 \%$ & 3 \\
\hline & 3 & 3 & $40 \%$ & 3 \\
\hline \multirow{4}{*}{4} & 1 & 3 & $40 \%$ & 4 \\
\hline & 2 & 3 & $40 \%$ & 4 \\
\hline & 3 & 3 & $40 \%$ & 4 \\
\hline & 4 & 3 & $40 \%$ & 4 \\
\hline \multirow{5}{*}{5} & 1 & 2 & $80 \%$ & 5 \\
\hline & 2 & 2 & $80 \%$ & 5 \\
\hline & 3 & 2 & $80 \%$ & 5 \\
\hline & 4 & 2,3 & $80 \%$ & 5 \\
\hline & 5 & 2,3 & $80 \%$ & 5 \\
\hline
\end{tabular}


Both tables show that allocating only one recycling bin is insufficient to cover the study area. However, by comparing these tables, increasing the $k$ and $P$ values has minimal coverage level impact. As can be seen, the number of recycling bin locations does not increase as $k$ increases, but the changes are plainly visible as $P$ increases. Meanwhile, significant changes in coverage level can be noted when $M$ is increased. As a result, from table 1 , to achieve $100 \%$ coverage, only one location $(j=5)$ with five recycling bins is required.

\section{Conclusions and Future Works}

Our work primarily contributes to determining optimal locations for recycling facilities and allocating sufficient bins in the selected study area. This is an alternative to the public's waste, especially households, to the landfill. It has also been found that studies relating to the location of recycling facilities in Malaysia using mathematical approaches are still limited. For these reasons, we updated and enhanced a classic location model, the MEXCLP, to estimate the position and distribution of recycling bins within chosen residential areas of Johor Bahru, a Malaysian municipality. We enhanced the MEXCLP model by limiting the total number of permissible recycling bins in each specified area. As a result, it is found that only five bins are required to cover the study area, and these bins are allocated to only one location. If recycling bins are strategically placed, more households are expected to practise recycling, directly enhancing Malaysia's recycling rates.

To conclude, our major contributions in this paper can be summarized into two-fold namely, (i) developing a mathematical model for recycling bins location-allocation problem for urban municipalities, and (ii) applying the proposed model for Malaysian urban household's municipality, which are still receiving less attention despite the fact that sustainable waste management is a growing topic. Hence, several improvements can be implemented in the future. Currently, Malaysian local authorities for several urban areas have established new plastic waste policies, providing an opportunity for further research into recycling facility location and allocation. The proposed model can be enriched by considering multiple types of recyclable waste can be added to the model, allowing different types of bins to be assigned to a recycling facility location. Additionally, users' and local authorities' choices for recycling facility locations would be considered in order to determine the most acceptable location. This could be conducted through a multi-objective approach by considering the operational cost of locating recycling facilities, or spatial interactive method.

\section{References}

Abas, M. A., \& Wee, S. T. (2016). Municipal Solid Waste Management in Malaysia: An Insight Towards Sustainability. SSRN Electronic Journal, January 2015. https://doi.org/10.2139/ssrn.2714755

Abdul Malik, N. K., Abdullah, S. H., \& Abd Manaf, L. (2015). Community Participation on Solid Waste Segregation Through Recycling Programmes in Putrajaya. Procedia Environmental Sciences, 30, 10-14. https://doi.org/10.1016/j.proenv.2015.10.002

Asefi, H., \& Lim, S. (2017). A novel multi-dimensional modeling approach to integrated municipal solid waste management. Journal of Cleaner Production, 166, 1131-1143. https://doi.org/10.1016/j.jclepro.2017.08.061

Blazquez, C., \& Paredes-Belmar, G. (2020). Network design of a household waste collection 
INTERNATIONAL JOURNAL OF ACADEMIC RESEARCH ECONOMICS AND MANAGEMENT SCIENCES

Vol. 10, No. 3, 2020, E-ISSN: 2226-3624 @ 2020 HRMARS

system: A case study of the commune of Renca in Santiago, Chile. Waste Management, 116(August), 179-189. https://doi.org/10.1016/j.wasman.2020.07.027

Boskovic, G., \& Jovicic, N. (2015). Fast methodology to design the optimal collection point locations and number of waste bins: A case study. Waste Management and Research, 33(12), 1094-1102. https://doi.org/10.1177/0734242X15607426

Compendium of Environment Statistics, Malaysia 2020. (2020). In Department of Statistic, Malaysia (Issue November).

https://www.dosm.gov.my/v1/index.php?r=column/pdfPrev\&id=TjM1ZIFxb3VOakdmMn ozVms5dUIKZz09

Daskin, M. S., Snyder, L. V, \& Berger, R. T. (2005). Facility Location in Supply Chain Design. In A. Langevin \& D. Riopel (Eds.), Logistics Systems: Design and Optimization (pp. 39-65). Springer US. https://doi.org/10.1007/0-387-24977-X_2

Demirbas, A. (2011). Waste management, waste resource facilities and waste conversion processes. Energy Conversion and Management, 52(2), 1280-1287.

https://doi.org/https://doi.org/10.1016/j.enconman.2010.09.025

Gilardino, A., Rojas, J., Mattos, H., Larrea-Gallegos, G., \& Vázquez-Rowe, I. (2017). Combining operational research and Life Cycle Assessment to optimize municipal solid waste collection in a district in Lima (Peru). Journal of Cleaner Production, 156, 589-603. https://doi.org/https://doi.org/10.1016/j.jclepro.2017.04.005

Hammim, R. (2019). Johor on lookout for best solution to manage solid waste. News Straits Times. $\quad$ https://www.nst.com.my/news/nation/2019/05/487596/johor-lookout-bestsolution-manage-solid-waste

Imran, A., Shreeshivadasan, C., Norhayati, A., \& Danish, M. A. (2019). Sanitary Landfill is a Solution in Solid Waste Management or a Silent Threat to Environment: Malaysian Scenario Article history. Open International Journal of Informatics (OIJI), 7(Special Issue), 135-146.

KeTTHA. (2017). Green Technology Master Plan (GTMP) 2017-2030. https://www.malaysia.gov.my/portal/content/30920

Khamaruddin, P. F., Tony, T. A., Alias, A. B., Aishah, S. A. S., \& Suhaili, E. Q. (2019). Waste Characteristics Study and Recycling Practice Trend at Tuanku Abdul Halim Mu'adzam Shah Engineering Complex, UiTM. Key Engineering Materials, 797(November), 65-73. https://doi.org/10.4028/www.scientific.net/KEM.797.65

Letelier, C., Blazquez, C., \& Paredes-Belmar, G. (2021). Solving the bin location-allocation problem for household and recycle waste generated in the commune of Renca in Santiago, Chile. Waste Management \& Research : The Journal of the International Solid Wastes and Public Cleansing Association, ISWA, 734242X20986610.

https://doi.org/10.1177/0734242X20986610

Michel Devadoss, P. S., Agamuthu, P., Mehran, S. B., Santha, C., \& Fauziah, S. H. (2021). Implications of municipal solid waste management on greenhouse gas emissions in Malaysia and the way forward. Waste Management, 119, 135-144.

https://doi.org/10.1016/j.wasman.2020.09.038

Harijani, M. A., Mansour, S., \& Karimi, B. (2017). A multi-objective model for sustainable recycling of municipal solid waste. Waste Management and Research, 35(4), 387-399. https://doi.org/10.1177/0734242X17693685

Moh, Y. C., \& Abd Manaf, L. (2014). Overview of household solid waste recycling policy status and 
INTERNATIONAL JOURNAL OF ACADEMIC RESEARCH ECONOMICS AND MANAGEMENT SCIENCES

Vol. 10, No. 3, 2020, E-ISSN: 2226-3624 @ 2020 HRMARS

challenges in Malaysia. Resources, Conservation and Recycling, 82, 50-61. https://doi.org/10.1016/j.resconrec.2013.11.004

Moh, Y. C., \& Abd Manaf, L. (2017). Solid waste management transformation and future challenges of source separation and recycling practice in Malaysia. Resources, Conservation and Recycling, 116(2017), 1-14. https://doi.org/10.1016/j.resconrec.2016.09.012

Musa, Z. (2021. Iskandar Malaysia green agenda to continue with two initiatives. The Star. https://www.thestar.com.my/metro/metro-news/2021/06/11/iskandar-malaysia-greenagenda-to-continue-with-two-initiatives

Ngoc, N. U., \& Schnitzer, H. (2009). Sustainable solutions for solid waste management in Southeast Asian countries. Waste Management, 29(6), 1982-1995. https://doi.org/10.1016/j.wasman.2008.08.031

Nowakowski, P., \& Mrówczyńska, B. (2018). Towards sustainable WEEE collection and transportation methods in circular economy - Comparative study for rural and urban settlements. Resources, Conservation and Recycling, 135(August 2017), 93-107. https://doi.org/10.1016/j.resconrec.2017.12.016

Rathore, P., Sarmah, S. P., \& Singh, A. (2020). Location-allocation of bins in urban solid waste management: a case study of Bilaspur city, India. Environment, Development and Sustainability, 22(4), 3309-3331. https://doi.org/10.1007/s10668-019-00347-y

Razali, F., Daud, D., Weng-Wai, C., \& Anthony Jiram, W. R. (2020). Waste separation at source behaviour among Malaysian households: The Theory of Planned Behaviour with moral norm. Journal of Cleaner Production, 271, 122025.

https://doi.org/10.1016/j.jclepro.2020.122025

Razali, F., Weng Wai, C., \& Daud, D. (2019). a Review of Malaysia Solid Waste Management Policies To Improve Recycling Practice and Waste Separation Among Households. International Journal of Built Environment and Sustainability, 6(1-2), 39-45. https://doi.org/10.11113/ijbes.v6.n1-2.381

Rosni, M. Z., Ishak, M. I., \& Zawawi, M. A. S. (2021). Recycling Facility Location-Allocation Model - A Case Study of Seremban, Malaysia. Universiti Teknologi MARA.

Annuar, S. (2019, June 15). Hanya 10 peratus kediaman asing sisa pepejal. Berita Harian Online, June. https://www.bharian.com.my/berita/nasional/2019/06/574547/hanya-10-peratuskediaman-bertingkat-asing-sisa-pepejal

Sharifah, A. S. A. K., Khamaruddin, P. F. M., Mohamad, N. N., \& Saharuddin, M. Q. (2018). Focussing on recycling attitudes of engineering students at UiTM Shah Alam - Towards zero discharge. IOP Conference Series: Materials Science and Engineering, 334(1). https://doi.org/10.1088/1757-899X/334/1/012034

Shuib, A., \& Zaharudin, Z. A. (2011). TAZ_OPT: A goal programming model for ambulance location and allocation. 2011 IEEE Colloquium on Humanities, Science and Engineering, 945-950. https://doi.org/10.1109/CHUSER.2011.6163878

Suhaini, N. A. (2019, May 29). 3,600 tan sehari sisa buangan di Johor. Berita Harian Online. https://www.bharian.com.my/berita/wilayah/2019/05/569324/3600-tan-sehari-sisabuangan-di-johor

Tan, S. T., Ho, W. S., Hashim, H., Lee, C. T., Taib, M. R., \& Ho, C. S. (2015). Energy, economic and environmental (3E) analysis of waste-to-energy (WTE) strategies for municipal solid waste (MSW) management in Malaysia. Energy Conversion and Management, 102, 111-120. 
https://doi.org/10.1016/j.enconman.2015.02.010

Tiew, K. G., Basri, N. E. A., Watanabe, K., Zain, S. M., Er, A. C., \& Deng, H. (2019). Higher educational institutions recycling management in Malaysia. International Journal of Business and Society, 20(1), 277-285.

Umar, U. A., Shafiq, N., \& Ahmad, F. A. (2021). A case study on the effective implementation of the reuse and recycling of construction \& demolition waste management practices in Malaysia. Ain Shams Engineering Journal, 12(1), 283-291. https://doi.org/10.1016/j.asej.2020.07.005

Yusoff, S. (2018). Toward integrated and sustainable waste management system in University of Malaya: UM zero waste campaign. E3S Web of Conferences, 48. https://doi.org/10.1051/e3sconf/20184804007

Zaharudin, Z. A., Brint, A., Genovese, A., \& Piccolo, C. (2021). A spatial interaction model for the representation of user access to household waste recycling centres. Resources, Conservation and Recycling, 168(December 2020), 105438. https://doi.org/10.1016/j.resconrec.2021.105438

Zaharudin, Z. A., Nordin, N. A. M., Tahir, H. M., Kamal, C. W. R. A. C. W., Ghani, N. H. A., \& Halim, N. H. A. (2012). An application of MEXCLP model: A case study for mobile ambulance location. CHUSER 2012 - 2012 IEEE Colloquium on Humanities, Science and Engineering Research, 539-543. https://doi.org/10.1109/CHUSER.2012.6504372 